\section{Peter Mair}

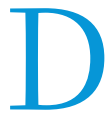

r. Peter Mair, Professor of Comparative Politics and Government at the EUI (Florence) has suddenly and unexpectedly passed away, 15 August 2011, at the age of 6o. He leaves behind his wife and 3 children. The political science community in Europe and beyond grieves this loss of an outstanding academic journal editor and teacher. Peter Mair, born 3 March 1951, was a native of Ireland, a graduate of University College Dublin and enjoyed a distinguished academic career and was the author of a large number of books, chapters and articles on comparative and European politics and on party democracy in particular. It is a sad loss to European political science. He graduated in 1974 and began his career as an assistant professor at the University of Limerick. He subsequently lectured at the universities of Strathclyde and Manchester before moving to the European University Institute of Florence in 1979. He moved to the University of Leiden in the Netherlands in 1987 and was appointed professor of comparative politics in 1992. In 2005 he returned to Florence and was appointed head of the department of political and social sciences in 2007. Prof Mair specialised in the study of party and party systems and has written a number of books on the subject. He was co-author of Representative Government in Modern Europe, the fifth edition of which was published this year. He was also co-author of Identity, Competition and Electoral Availability, which was awarded the prestigious Stein Rokkan prize. Peter Mair served the comparative political science community by editorships of the internationally reputed European Journal of Political Science and of West European Politics. Peter was a person of great charm, a congenial colleague and always encouraging students. We grieve over his loss and sympathize with his family he left behind too early and too soon.

Prof. Hans Keman (VU University)Chair in Comparative Political Science, Vrije Universiteit (VU Amsterdam) 